\title{
Effects of Chaenomeles maulei Fruit Juice on Reserpine-induced Behavioral Changes in Rats
}

\author{
Vesela A. Borisova, Miroslav Tz. Eftimov, Stefka V. Valcheva-Kuzmanova \\ Department of Pharmacology and Clinical Pharmacology and Therapeutics, Medical University, Varna, Bulgaria \\ Corresponding author: Stefka V. Valcheva-Kuzmanova, Department of Pharmacology and Clinical Pharmacology and Therapeutics, Prof. Dr. Para- \\ skev Stoyanov Medical University, 55 Marin Drinov St., 9002 Varna, Bulgaria; E-mail: stefkavk@yahoo.com; Tel.: +35952677078
}

Received: 15 May 2019 Accepted: 21 June 2019 Published: 31 Dec 2019

Citation: Borisova VA, Eftimov MT, Valcheva-Kuzmanova SV. Effects of Chaenomeles maulei fruit juice on reserpine-induced behavioral changes in rats. Folia Med (Plovdiv) 2019;61(4):579-83. doi: 10.3897/folmed.61.e47810.

\begin{abstract}
Background: The fruit juice from Chaenomeles japonica var. maulei (Mast.) Lavall,e is very rich in polyphenolic compounds.

Aim: The aim of the current study was to investigate the effects of Chaenomeles maulei fruit juice (CMFJ) on reserpine-induced behavioral changes in rats.

Materials and methods: The experimental design included a total of 50 animals, divided in the following groups: control, R, $\mathrm{R}+\mathrm{CMFJ}_{2.5}, \mathrm{R}+\mathrm{CMFJ}_{5}$, and $\mathrm{R}+\mathrm{CMFJ}_{10}$. All groups except the control received a single intraperitoneal injection of reserpine while the Control group was injected with the vehicle. CMFJ was applied through an orogastric cannula at 0,19 , and 23 hours after reserpine injection at doses of $2.5 \mathrm{ml} / \mathrm{kg}, 5 \mathrm{ml} / \mathrm{kg}$, and $10 \mathrm{ml} / \mathrm{kg}$ to groups $\mathrm{R}+\mathrm{CMFJ}_{2.5}, \mathrm{R}+\mathrm{CMFJ}_{5}$, and $\mathrm{R}+\mathrm{CMFJ}_{10}$, respectively. The groups control and $\mathrm{R}$ received distilled water $(10 \mathrm{ml} / \mathrm{kg})$ at the same time points. The open field test (OFT) and the forced swim test (FST) were carried out. In the OFT, crossings and rearings were recorded as a measure of locomotor activity. In the FST, the immobility time served as a measure of depressive-like behavior.
\end{abstract}

Results: In the OFT, the number of crossings of rats were significantly reduced $(\mathrm{p}<0.05)$ by reserpine. CMFJ antagonized the effects of reserpine on rat locomotor activity. In the FST, reserpine caused an insignificant reduction of the immobility time while CMFJ reversed this effect probably by increasing the locomotor activity.

Conclusion: CMFJ reversed reserpine-induced hypokinesia in rats. This effect of CMFJ might be attributed to the polyphenols found in very high concentrations in the juice.

\section{Keywords}

Chaenomeles maulei fruit juice, locomotor activity, polyphenols, reserpine, rats

\section{INTRODUCTION}

Reserpine is an alkaloid, derived from Rauwolfia serpentina or Indian snakeroot. Used in the past as an antihypertensive drug, now its use is limited. ${ }^{1}$ The mechanism of action of reserpine involves depletion of catecholamines stores and reduction of sympathetic activity. Reserpine causes a reduction of dopamine levels at the insula ${ }^{2}$ and oxidative stress in rat brains ${ }^{3,4}$. It induces anhedonic-like state, lo- comotor hypokinesia, reduced body temperature and alterations in the sucrose-preference test. ${ }^{5}$ These behavioral changes may be observed as increased immobility in the forced swim and tail suspension tests ${ }^{6}$ and are highly similar to some aspects of depression in humans.

The currently accepted theory of depression describes a decreased level of the major neurotransmitters: norepinephrine, serotonin, and dopamine in the synapse. Therefore, the mechanisms of action of antidepressants are 
directed towards the increase of these neurotransmitter levels. The conventionally used antidepressants show some disadvantages like slow onset of action and side effects, frequently decreasing the patient's compliance. A better tolerated alternative are the plant sources, rich in polyphenolic compounds. They have shown to be effective in the treatment of neuropsychological disorders. ${ }^{7}$

Chaenomeles japonica var. maulei (Mast.) Lavall,e is a polyphenol-rich plant, widely used in the traditional Chinese medicine, belonging to the Chaenomeles genus. There are five wild Chaenomeles species in China including Chaenomeles speciosa, Chaenomeles thibetica, Chaenomeles cathayensis, Chaenomeles sinensis, and Chaenomeles japonica. Chaenomeles maulei is a variety of Chaenomeles japonica, cultivated mainly in Europe and some parts of Russia. Polyphenols, such as flavonoids and phenolic acids, found at high concentrations in Chaenomeles species fruits, are known for their protective effects against cardiovascular diseases and exhibit anti-cancer, antimicrobial, antiinflammatory, antioxidant and neuroprotective action. ${ }^{8}$

The Chaenomeles plants are poorly studied for their effects on the central nervous system. This study aimed to investigate the effects of Chaenomeles maulei fruit juice $(\mathrm{CMFJ})$ in a model of reserpine-induced behavioral changes in rats.

\section{MATERIALS AND METHODS}

\section{Experimental substances}

Chaenomeles maulei fruit juice was produced from plants grown in the Balkan Mountains, Bulgaria, in the region of Troyan. After handpicking, fresh fruits were grinded, crushed and squeezed. The juice was filtered, preserved with potassium sorbate $(1.0 \mathrm{~g} / \mathrm{l})$ and stored at $0^{\circ} \mathrm{C}$ till the experiments. The total content of phenolic compounds was determined by the spectrophotometric Folin-Ciocalteu assay. ${ }^{9}$ Absorbance was read at $760 \mathrm{~nm}$. Gallic acid was used as a standard. The spectrophotometric assay showed a very high content of phenolic compounds $-8900.00 \mathrm{mg}$ gallic acid equivalents per liter of juice. The high content of polyphenols was confirmed by an HPLC analysis that revealed the presence of phenolic acids and flavonoids. The phenolic acids were presented in the highest concentration by vanillic acid, caffeic acid and chlorogenic acid. ${ }^{10}$ From the flavonoids, the most abundant were epicatechin, catechin and quercetin. ${ }^{10}$

Reserpine (Sigma-Aldrich, USA) was provided in the form of a powder.

\section{Animals}

The animals used were healthy male Wistar rats with a mean weight of $220 \pm 30 \mathrm{~g}$, bred in the Animal Centre of Medical University of Varna. The animals were housed in plastic cages in a well-ventilated room maintained at $22 \pm 1^{\circ} \mathrm{C}$ and on a $12 / 12$ light/dark cycle. They received standard rodent pelleted diet and water ad libitum.

All procedures concerning animal treatment and experimentation were conducted in conformity with the national and international laws and policies (EU Directive 2010/63/ EU for animal experiments) and were approved by Bulgarian Food Safety Agency (document 141/23.06.2016).

\section{Experimental design}

A total of 50 animals were divided into 5 groups $(n=10)$ : Control, $\mathrm{R}$ (reserpine), $\mathrm{R}+\mathrm{CMFJ}_{2.5}, \mathrm{R}+\mathrm{CMFJ}_{5}$ and $\mathrm{R}+\mathrm{CMFJ}_{10}$. All animals except the controls received a single dose of reserpine. Reserpine was freshly dissolved at a dose of $6 \mathrm{mg} / \mathrm{kg}$ in 5\% dimethyl sulfoxide (DMSO)/saline solution and administered intraperitoneally (i.p.) in a volume of $1 \mathrm{ml} / \mathrm{kg}$. Control animals were injected only with the vehicle (5\% DMSO, $1 \mathrm{ml} / \mathrm{kg}$, i.p.). $\mathrm{R}+\mathrm{CMFJ}_{2.5}, \mathrm{R}+\mathrm{CMFJ}_{5}$ and $\mathrm{R}+\mathrm{CMFJ}_{10}$ groups received CMFJ orally at doses of $2.5 \mathrm{ml} /$ $\mathrm{kg}, 5 \mathrm{ml} / \mathrm{kg}$, and $10 \mathrm{ml} / \mathrm{kg}$, respectively. The doses of $2.5 \mathrm{ml} /$ $\mathrm{kg}$ and $5 \mathrm{ml} / \mathrm{kg}$ were diluted with distilled water to $10 \mathrm{ml} /$ $\mathrm{kg}$. The control and $\mathrm{R}$ groups received distilled water at a dose of $10 \mathrm{ml} / \mathrm{kg}$. CMFJ was applied through an orogastric cannula on the $0^{\text {th }}, 19^{\text {th }}$ and $23^{\text {rd }}$ hour after reserpine or vehicle injection.

\section{Open field test}

The open field test (OFT) was carried out 1 hour after the last oral treatment. The OFT is one of the experimental paradigms initially introduced to estimate the locomotor activity and willingness of animals to explore. ${ }^{11}$ The test allows measuring the behavior of an animal after it is released into an open, novel arena. ${ }^{12}$ The open field was a wooden arena $(100 \times 100 \times 40 \mathrm{~cm})$ painted white. The floor was divided with blue paint into 25 equal-size squares. The duration of the test session for each animal was $5 \mathrm{~min}$. The measure for the horizontal activity was the number of squares crossed with four paws (crossings). The vertical activity was measured by the times the animal stood on its hind limbs (rearings).

\section{Forced swim test}

The forced swim test (FST) was carried out in two sessions. The training session took place 1 hour after the OFT while the test session took place exactly 24 hours after the training session. Because of its relative simplicity, the FST has become a widely used procedure in the screening of antidepressant drugs. Also known as the Porsolt test, FST measures an animal's response to an inescapable situation and allows the assessment of "behavioral despair". ${ }^{13}$ The animals were tested one by one in a transparent glass cylinder (17 $\mathrm{cm}$ in diameter and $60 \mathrm{~cm}$ in height) filled partially with water $\left(22 \pm 1^{\circ} \mathrm{C}\right)$, so that there was space left, but not allowing the animals to escape. Each animal was dropped down in water and its activity was documented for $5 \mathrm{~min}$ and the 
results from the test session were recorded. There was an initial period of high activity when the animal tried to escape. Eventually, this activity ceased and there was a specific immobility period. We assessed the immobility time, described as the effort required to keep the animal's head above the water. The longer duration of the immobility time is related to increased behavioral despair while antidepressant drugs decrease the immobility time. ${ }^{14}$

\section{Statistical analysis}

The results obtained were expressed as mean \pm SEM. The data were analysed by one-way ANOVA, followed by Dunnett's multiple comparison post hoc test. A level of $\mathrm{p}<0.05$ was considered significant. All analyses were performed using GraphPad Prism statistical software.

\section{RESULTS}

\section{Open field test}

The results from the horizontal activity, measured as the number of crossings are presented in Fig. 1. The number of crossings of the control group were $74.8 \pm 11.5$. The administration of reserpine caused a significant decrease in the horizontal activity $(36.6 \pm 8.0 ; \mathrm{p}<0.05$ vs. control). CMFJ managed to recover the locomotor activity of reserpinetreated rats. The number of crossings of CMFJ-treated rats did not differ significantly from the results of the control group. The horizontal activity of $\mathrm{R}+\mathrm{CMFJ}_{2.5}$ and $\mathrm{R}+\mathrm{CMFJ}_{5}$ groups was $45.0 \pm 10.5$ and $43.2 \pm 10.5$, respectively. The result of $\mathrm{R}+\mathrm{CMFJ}_{10}$ group $(56.6 \pm 12.0)$ was closest to that of the control group.

The vertical activity of the $\mathrm{R}$ group was lower $(14.7 \pm 2.1)$ than that of the control group $(22.1 \pm 3.2)$, but the results were not significantly different as shown in Fig. 2. The number of rearings of rats belonging to $\mathrm{R}+\mathrm{CMFJ}_{2.5}$ and

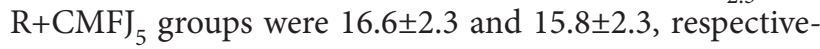
ly. These results were similar to the result of the $\mathrm{R}$ group. $\mathrm{R}+\mathrm{CMFJ}_{10}$ group showed a significant elevation in the vertical activity compared to $\mathrm{R}$ group $(26.3 \pm 4.0 ; \mathrm{p}<0.05$ vs. $\mathrm{R}$ group).

\section{Forced swim test}

The immobility time of $\mathrm{R}$ group $(60.0 \pm 7.4 \mathrm{sec})$ was not significantly different from that of the Control group $(56.5 \pm 4.0 \mathrm{sec})$. The treatment with CMFJ caused a tendency to decrease the immobility time to values of $56.7 \pm 6.2 \mathrm{sec}$, $48.3 \pm 7.9 \mathrm{sec}$ and $45.3 \pm 4.4 \mathrm{sec}$ for the animals belonging to $\mathrm{R}+\mathrm{CMFJ}_{2.5}, \mathrm{R}+\mathrm{CMFJ}_{5}$ and $\mathrm{R}+\mathrm{CMFJ}_{10}$ groups, respectively. The immobility time of $\mathrm{CMFJ}_{10}$ group was lower than that of R group and even than that of the control group, without reaching statistical significance (Fig. 3).

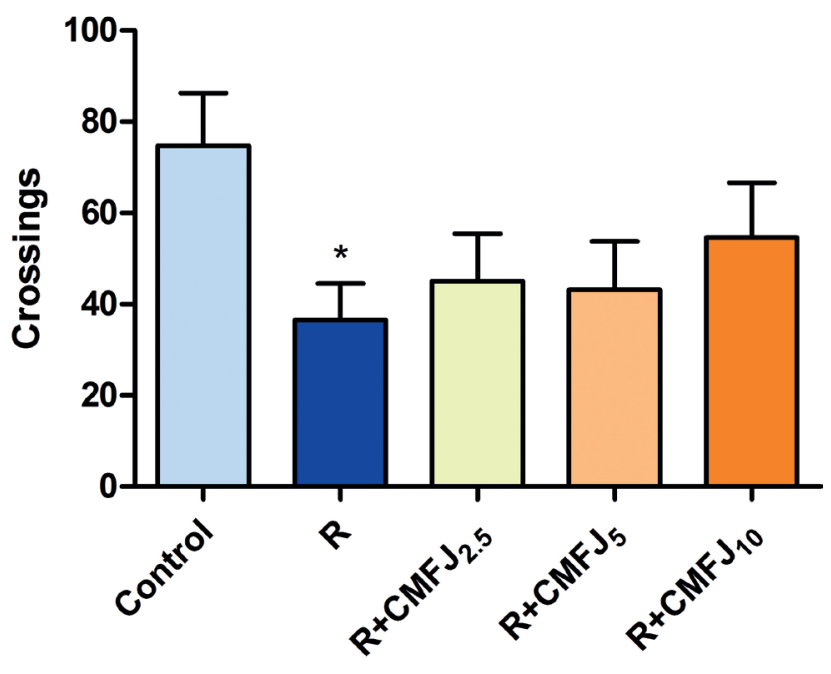

Figure 1.

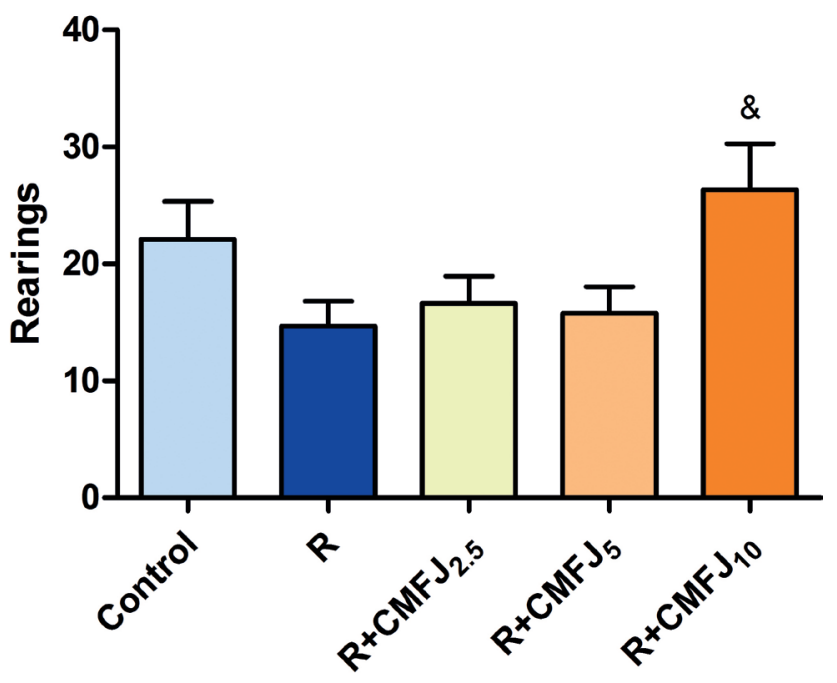

Figure 2

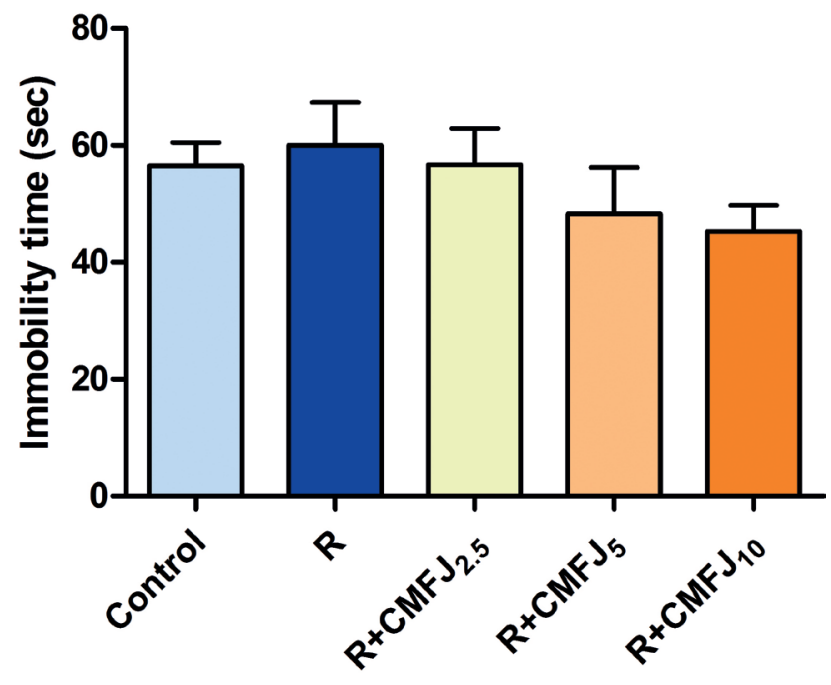

Figure 3 


\section{DISCUSSION}

Reserpine is a long known substance with a mechanism of action involving the depletion of brain monoamines due to the irreversible block of the vesicular monoamine transporter. The behaviours produced by its administration, such as anhedonic-like state and decreased locomotion, might be interpreted as depressive-like and Parkinson's disease-like symptoms. Both of these disorders include the decreased levels of monoamines in the synapse, especially dopamine. ${ }^{15}$ In the present study, the administration of reserpine induced a dose-dependent hypokinesia in the OFT, which was in agreement with the findings of Qingjun et al. ${ }^{16}$ Dopamine reuptake blockers or direct dopamine agonists induce the locomotor activity in rats. ${ }^{17}$ Dopamine transporter inhibition in the substantia nigra might prevent drug-induced dyskinesia or when in the mesolimbic system, be responsible for the reversal of anhedonia. ${ }^{18}$

The administration of CMFJ showed a dose-dependent tendency to reverse the reserpine-induced hypokinesia. These effects might be explained with the high concentration of polyphenols in the CMFJ. Phenolic acids and flavonoids are the main active ingredients found in CMFJ. Dietary polyphenols are known to modulate the monoaminergic system by increasing the synthesis or interaction with dopamine and serotonin receptors. ${ }^{19,20}$ Previous findings suggest that the polyphenols in other Chaenomeles plants modulate the effects of the catecholamines. Chaenomeles speciosa dried fruits have been shown to inhibit the activity of dopamine transporter and thus elevate the levels of dopamine in the synapse. ${ }^{21}$ A similar action of CMFJ in this study might explain its effect to antagonize reserpineinduced hypokinesia.

The dysregulation of dopaminergic system, especially the mesolimbic reward pathway, might be a possible mechanism involved in the pathogenesis of depression. ${ }^{22}$ In the current study, however, the single injection of reserpine did not produce a significant elevation of the immobility time in the FST. Since the full clinical manifestation of depression requires time, we suggest that the slight prolongation of the immobility time in this acute setting of administration of reserpine was due to the decreased locomotor activity of the animals. CMFJ at the dose of $10 \mathrm{ml} / \mathrm{kg}$ managed to reduce most markedly, but not significantly, the immobility of animals. The administration of CMFJ antagonized the effect of reserpine, probably by increasing the locomotion, rather than affecting the depressive-like state.

\section{CONCLUSION}

In conclusion, this study showed that administration of CMFJ reversed reserpine-induced hypokinesia in the OFT, which might be associated with monoaminergic modulation. The effects of reserpine and CMFJ on the immobility in the FST were not significant and might be explained with the effects on locomotion. The effects of CMFJ might be at- tributed to the polyphenols found in very high concentrations in the juice.

\section{REFERENCES}

1. Panda SK, Das D, Tripathy BN, et al. Phyto-pharmacognostical studies and quantitative determination of reserpine in different parts of Rauwolfia ( spp.) of Eastern Odisha by UV spectroscopy method. Asian J Plant Sci Res 2012; 2(2): 151-62.

2. Ruiz P, Calliari A, Pautassi RM. Reserpine-induced depression is associated in female, but not in male, adolescent rats with heightened, fluoxetine-sensitive, ethanol consumption. Behav Brain Res 2018; 348: 160-70.

3. Bilska A, Dubiel M, Sokolowska-Jez'ewicz M, et al. Alpha-lipoic acid differently affects the reserpine-induced oxidative stress in the striatum and prefrontal cortex of rat brain. Neuroscience 2007; 146(4): 1758-71.

4. Eftimov M, Dobreva C, Velkova D, et al. Effect of Aronia melanocarpa fruit juice on reserpine-induced hypokinesia and oxidative stress in rats. Scr Sci Pharma 2014; 1(2): 29-34.

5. Leith NJ, Barrett RJ. Effects of chronic amphetamine or reserpine on self-stimulation responding: animal model of depression? Psychopharmacol 1980; 72: 9-15.

6. Chang CY, Guo HR, Tsai WC, et al. Subchronic arsenic exposure induces anxiety-like behaviors in normal mice and enhances depression-like behaviors in the chemically induced mouse model of depression. Biomed Res Int 2015; 2015: 159015.

7. Ogle WO, Speisman RB, Ormerod BK. Potential of treating age-related depression and cognitive decline with nutraceutical approaches: a mini review. Gerontology 2013; 59: 23-31.

8. Du H, Wu J, Li H, et al. Polyphenols and triterpenes from Chaenomeles fruits: Chemical analysis and antioxidant activities assessment. Food Chem 2013; 141: 4260-8.

9. Singleton VL, Rossi JA. Colorimetry of total phenolics with phosphomolybdic-phosphotungstic acid reagents. Am J Enol Vitic 1965; 16: 144-58.

10. Valcheva-Kuzmanova SV, Denev PN, Ognyanov MH. Chemical composition and antioxidant activity of Chaenomeles maulei fruit juice. J Biomed Clin Res 2018; 11(1): 41-8.

11. Perals DG, Griffin AS, Batomeus I, et al. Revisiting the open-field test: what does it really tell us about animal personality? Animal Behaviour 2017; 123: 69-79.

12. Carola V, D'Olimpio F, Brunamonti E, et al. Evaluation of the elevated plus-maze and open-field tests for the assessment of anxiety-related behaviour in inbred mice. Behav Brain Res 2002; 134: 49-57.

13. Porsolt RD, Le Pichon M, Jalfre M. Depression: a new animal model sensitive to antidepressant treatments. Nature 1977; 266: 730-2.

14. Hoffman KL. What can animal models tell us about depressive disorders? In: Modeling neuropsychiatric disorders in laboratory animals. 1st ed. Cambridge: Woodhead Publishing; 2015; 35-86.

15. Colpaert FC. Pharmacological characteristics of tremor, rigidity and hypokinesia induced by reserpine in rat. Neuropharmacol 1987; 26: 1431-40.

16. Qingjun H, Xinling H, Minor TR. Adenosina A2a receptor mediates reserpine-induced depression in rats. Acta Pshycol Sin 2003; 35 : 106-11.

17. Schindler C, Carmona G. Effects of dopamine agonists and antagonists on locomotor activity in male and female rats. Pharm Biochem 
Behav 2002; 72(4): 857-63.

18. Willner P, Hale AS, Argyropoulos S. Dopaminergic mechanism of antidepressant action in depressed patients. J Affect Disord 2005; 86: 37-45.

19. Machado DG, Bettio LE, Cunha MP, et al. Antidepressant-like effect of the extract of Rosmarinus officinalis in mice: Involvement of the monoaminergic system. Progress in Neuro-Psychopharmacology and Biological Psychiatry 2009; 33: 642-50.
20. Sasaki K, El Omri A, Kondo S, et al. Rosmarinus officinalis polyphenols produce anti-depressant like effect through monoaminergic and cholinergic functions modulation. Behav Brain Res 2013; 238: 86-94.

21. Zhao G, Jiang Z, Zheng X, et al. Dopamine transporter inhibitory and antiparkinsonian effect of common flowering quince extract. Pharmacol Biochem Behav 2008; 90(3): 363-71.

22. Papakostas GI. Dopaminergic-based pharmacotherapies for depression. Eur Neuropsychopharmacol 2006; 16: 391-402.

\title{
Влияние фруктового сока из Chaenomeles maulei на резерпин-индуцированные изменения поведения у крыс
}

\author{
Весела А. Борисова, Мирослав Ц. Евтимов, Стефка В. Валчева-Кузманова \\ Кафедра фармакологии и клинической фармакологии и терапии, Медицинский университет -Варна, Варна, Болгария
}

Адрес для корреспонденции: Стефка В. Валчева-Кузманова, Кафедра фармакологии и клинической фармакологии и терапии, Медицинский университет „Проф. Д-р Параскев Стоянов”, ул. „Марин Дринов” № 55, 9002 Варна , Болгария; E-mail: stefkavk@yahoo.com; тел: $+35952677078$

Дата получения: 15 мая 2019 Дата приемки: 21 июня 2019 Дата публикации: 31 декабря 2019

Образец цитирования: Borisova VA, Eftimov MT, Valcheva-Kuzmanova SV. Effects of Chaenomeles maulei fruit juice on reserpine-induced behavioral changes in rats. Folia Med (Plovdiv) 2019;61(4):579-83. doi: 10.3897/folmed.61.e47810.

\section{Абстракт}

Введение: Фруктовый сок из Chaenomeles japonica рода maulei (Mast.) очень богат полифенольными соединениями.

Цель: Целью данного исследования было изучение влияния фруктового сока из Chaenomeles maulei (ФСХМ) на вызванные резерпином изменения поведения у крыс.

Материалы и методы: Методика исследования включала в себя 50 животных, разделённых на следующие группы: контрольная, R, R + PSXM5.5, R + PSXM5 и R + PSXM10. Всем животным в группах, кроме контрольной, вводили одну внутрибрюшинную инъекцию резерпина, тогда как контрольной группе вводили растворитель. ФСХМ вводили через орогастральную канюлю в 0, 19 и 23 градусах после инъекции резерпина в дозах 2,5 ml/kg, $5 \mathrm{ml} / \mathrm{kg}$ и $10 \mathrm{ml} / \mathrm{kg}$ соответственно для групп R, $\mathrm{R}+\mathrm{PSXM} 2,5, \mathrm{R}$ + PSXM5 и R + PSXM10. Контрольной группе и группе R вводили дистиллированную воду (10 ml/ $\mathrm{kg})$ в те же периоды времени. Были проведены тесты открытого поля (ТОП) и тест принудительного плавания (ТПП). Горизонтальные движения (пересечение квадратов) и вертикальные движения (подъём задних лап) как показатели двигательной активности были измерены для ТОП и ТПП. При ТПП время неподвижности служило индикатором депрессивного поведения.

Результаты: В ТОП количество вертикальных движений крыс было значительно снижено (p <0,05) за счет резерпина. ФСХМ противодействует влиянию резерпина на двигательную активность крыс. При ТПП резерпин вызывал значительное сокращение времени неподвижности, тогда как ФСХМ полностью изменял этот эффект, вероятно, за счет увеличения двигательной активности.

Выводы: ФСХМ изменяет в противоположную сторону процесс резерпин-индуцированной гипокинезии у крыс. Этот эффект ФСХМ можно отнести к полифенолам, обнаруженным при очень высоких концентрациях в соке.

\section{Ключевые слова}

фруктовый сок из Chaenomeles maulei, полифенолы, двигательная активность, резерпин, крысы 